\title{
Acute Hemorrhagic Incarceration of Prolapsed Giant Rectal Tubulovillous Adenoma: A Rare Case of Anorectal Emergency
}

\section{Prolabe Dev Rektal Tübülovillöz Adenomun Akut Hemorajik İnkarserasyonu: Nadir Bir Anorektal Acil Olgusu}

\author{
(1) Osman Erdoğan1, (1) Zafer Teke1, (1) İshak Aydın2, (1) Ahmet Rencüzoğulları2 \\ ${ }^{1}$ Çukurova University Faculty of Medicine, Department of Surgical Oncology, Adana, Turkey \\ ${ }^{2}$ Çukurova University Faculty of Medicine, Department of General Surgery, Adana, Turkey
}

\section{\|IIIIIII ABSTRACT}

Colorectal adenomas are polyps that arise from the mucosa and demonstrate neoplastic features. Increasing dysplasia and malignant potential of adenomas are related to their size, villous component, and patient's age. Giant villous polyps of the rectum represent a real potential for an anorectal emergency. They may be involved in rectal bleeding, obstruction, prolapse, or incarceration. We herein present a case of a 57-year-old man presented to the emergency department because of an incarcerated transanal prolapse of a giant hemorrhagic tubulovillous rectal adenoma, which caused clinical symptoms and signs that were mistaken for prolapsed hemorrhoids, and was treated successfully by transanal excision.

Keywords: Rectal polyp, tubulovillous adenoma, prolapse, incarceration, transanal excision

\section{||l||||||| ÖZ}

Kolorektal adenomlar, mukozadan kaynaklanan ve neoplastik özellikler gösteren poliplerdir. Artan displazi ve malignite potansiyeli, adenomun boyutu, içerdiği villöz komponent ve hasta yaşı ile ilişkilidir. Dev rektal villöz polipler, gerçek bir anorektal acil potansiyeli taşırlar. Rektal kanama, obstrüksiyon, prolapsus ve inkarserasyona sebep olabilirler. Biz de bu yazımızda acil servisimize başvuran 57 yaşında erkek bir hastada, klinik semptom ve bulguları prolabe hemoroid ile karışan, başarılı bir şekilde transanal eksizyon yaptı̆̆ımız, anüsten prolabe olmuş inkarsere hemorajik dev rektal tübülovillöz adenom olgusunu sunmayı amaçladık.

Anahtar Kelimeler: Rektal polip, tübülovillöz adenom, prolapsus, inkarserasyon, transanal eksizyon

\section{Introduction}

Colorectal polyps are classified histologically as either neoplastic (which may be benign or malignant), adenomatous polyps (including serrated adenomatous) or non-neoplastic polyps (including hyperplastic, mucosal, inflammatory, and hamartomatous). Adenomatous polyps are found in approximately $33 \%$ of the general population by age 50 and in approximately $50 \%$ of the general population by age 70 . Most lesions are less than $1 \mathrm{~cm}$ in size, with $60 \%$ of people having a single adenoma and $40 \%$ having multiple lesions. Sixty percent of lesions will be located distal to the splenic flexure. ${ }^{1}$ Prolapsing anorectal polyps may mimic benign anorectal conditions such as prolapsed hemorrhoids and cause treatment dilemmas in an emergency setting. This study aimed to present a patient with acute hemorrhagic incarceration of prolapsed giant rectal adenomatous polyp that was treated successfully by transanal excision.

\section{Case Report}

A 57-year-old male patient was admitted to our emergency department with an incarcerated hemorrhagic mass protruding from the anal canal. He had a prolapsing rectal 
mass approximately for two years, although he always refused further colonoscopic evaluation or surgical treatment since the mass was relocated spontaneously. On admission, he did not refer to abdominal pain or diarrhea. He mentioned chronic constipation and rarely the urgency of defecation. Physical examination did not reveal abdominal pain or signs of intestinal obstruction. On rectal inspection in the lithotomy position, an incarcerated prolapsed mass of $15 \mathrm{~cm}$ in diameter that looked like cauliflower was seen (Figure 1). The mass was foul-smelling and had a necrotic surface and erosion. Hemoglobin was $11.7 \mathrm{~g} / \mathrm{dL}$, and other biochemical values were normal. Computed tomography with oral and intravenous contrast revealed prolapsing rectum and perirectal fat tissue from the anal canal. The hemorrhagic polyp protruding from the anal canal was removed by transanal excision under general anesthesia. Clean surgical margins were obtained by transanal excision of the mass and underlying muscular layer as a single piece (Figure 2). No postoperative complications occurred. The $12 \times 8 \times 5 \mathrm{~cm}$ mass was determined in pathologic examination to be a tubulovillous adenoma with intramucosal carcinoma (Figure 3). There was no lymphovascular invasion, and the mass was low-grade and well-to-moderately differentiated. No further treatment was recommended.

\section{Discussion}

Polyps occur in all parts of the colon. There are three main histologic variants of adenomatous polyps, namely tubular, villous, or tubulovillous. According to the World Health Organization criteria, tubular adenomas have less than $25 \%$ villous component, tubulovillous have $25-75 \%$, and villous have greater than $75 \% .^{2}$ Tubular adenomas are the most common type of adenoma, followed by tubulovillous and villous. Tubular adenomas are found with equal distribution throughout the colon. Villous adenomas have a predilection

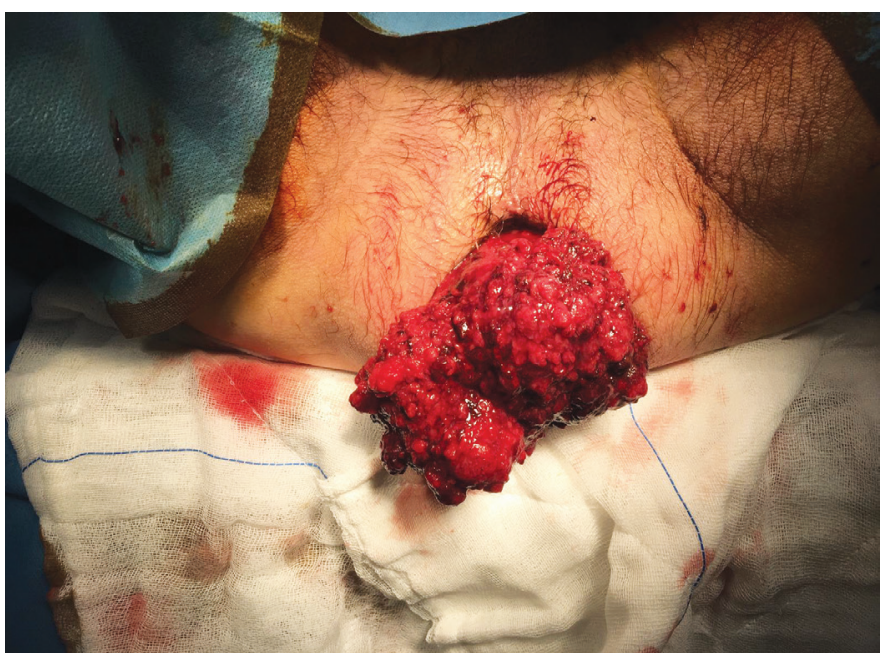

Figure 1. Preoperative image of giant rectal tubulovillous adenoma protruded from the anus for the rectum. They may be asymptomatic or related to mucous excretion, diarrhea, electrolyte imbalance, bleeding, or obstruction. ${ }^{3,4}$ Tubular adenomas have $<5 \%$ of harboring cancer, while the risk of tubulovillous is $20-25 \%$, and villous adenomas are $35-40 \% .^{5}$

Polyps are characterized by their size and morphology, which are two important features that may predict underlying malignancy and should guide how polyps are managed. They may be pedunculated (usually tubular or tubulovillous), sessile (usually tubulovillous or villous), or non-polypoid (flat or depressed). Small adenomas $(<1 \mathrm{~cm})$ are associated with malignancy in only $1.3 \%$ of cases, while adenomas $>2$ $\mathrm{cm}$ harbor malignancy $46 \%$ of times. Adenomatous polyps with mild, moderate, and severe dysplasia are found to have malignant cells on complete excision of the polyp in $5.7 \%$, $18 \%$, and $34.5 \%$ of the time, respectively. ${ }^{1}$ As defined by the United States National Polyp Study, an advanced adenoma is one that is $\geq 1 \mathrm{~cm}$ in size or contains high-grade dysplasia or invasive cancer. Villous change, left-sided location, and age $\geq 60$ were also associated with advanced pathologic features. ${ }^{6}$ Approximately $3 \%$ to $5 \%$ of adenomatous polyps harbor invasive carcinoma at the time of diagnosis. If a

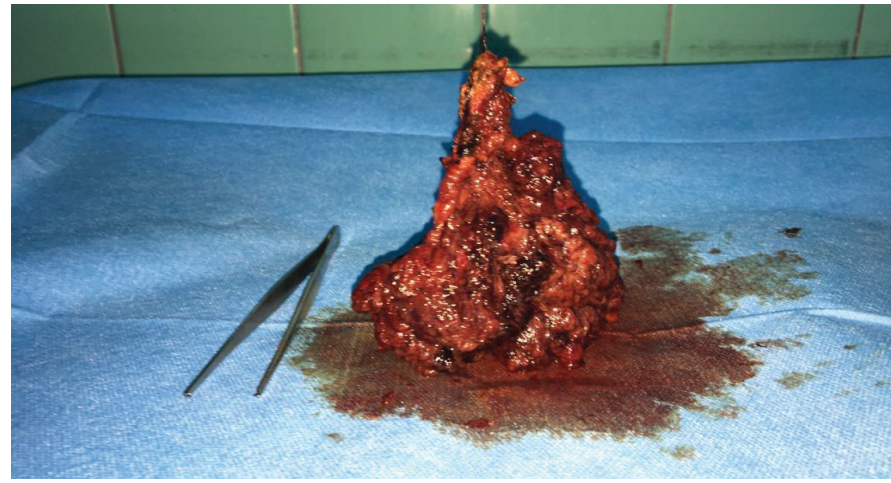

Figure 2. The excised specimen

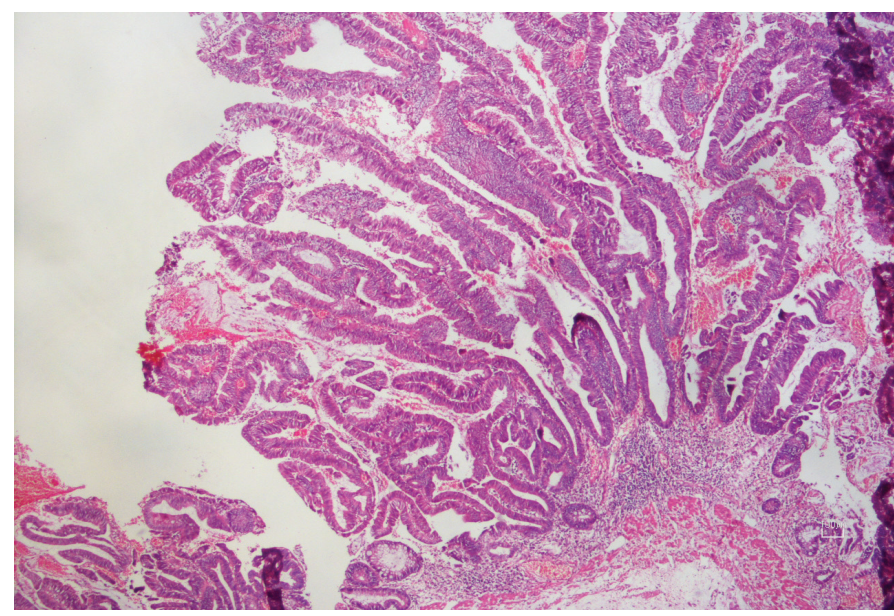

Figure 3. Microscopic image of rectal polyp stained with hematoxylin and eosin. Tubulovillous adenoma containing an intramucosal carcinoma focus (x10) 
polyp containing high-grade dysplasia is completely excised, the patient may be considered cured. A negative resection margin has consistently been shown to be associated with a decreased risk for an adverse outcome (recurrence, residual carcinoma, lymph node metastases, and decreased survival). Our patient's polyp was removed with a negative resection margin and identified in the pathologic evaluation as a tubulovillous polyp with intramucosal carcinoma in the polyp head. There was no invasion of the polyp stalk. Multiple mechanisms are related to polyps that prolapse through the anus. It seems that this condition is seen more often in children because during the first years of life there is less fat in the ischiorectal fossa, and so there is less pressure provided for this functional component of the perineum. ${ }^{7,8,9}$ Increased straining during bowel movements triggered by diarrhea, a common condition at this age, may also play a role. ${ }^{7,8}$ In adults, the main predisposing factors for prolapse include defects or dysfunction of the anal sphincter or conditions that induce increased intra-abdominal pressure, such as chronic constipation. ${ }^{10}$ In our case, the patient had no apparent alterations in the integrity of the anal sphincter that predispose to prolapse, but he suffered from constipation. Although there is no consensus as to how to treat prolapsed polyps, the options include conservative treatment, endoscopic resection, or even ultralow anterior resection. ${ }^{11}$ Colonoscopic polypectomy is safe and effective for the excision of nearly all pedunculated polyps. For polyps not amenable to polypectomy such as large sessile villous lesions, surgical resection is recommended. Fungating, ulcerated, or distorted lesions destroying the surrounding bowel wall indicate the presence of invasive cancer and are contraindications to polypectomy. Surgical resection is also indicated for patients with residual invasive carcinoma and those at high risk for lymph node metastases despite complete endoscopic polypectomy. Large villous adenomas of the rectum may be amenable to transanal local excision, and this provides complete diagnostic evaluation for malignancy, and if excised with negative margins (with other favorable prognostic features), it may be the only therapeutic procedure needed. In our case, the transanal polypectomy was successful.

Finally, since patients with anorectal adenomatous polyps have a well-established increased risk of malignancies, screening, and surveillance programs are recommended. ${ }^{12}$ Patients with 3-10 adenomas, any adenoma $\geq 1 \mathrm{~cm}$, any adenoma with villous features, or high-grade dysplasia should have their next colonoscopy in 3 years provided the entire polyp was removed in a non-piecemeal fashion. ${ }^{13,14}$

\section{Ethics}

Informed Consent: Patient was informed about the study and written informed consent form was obtained.
Peer-review: Extenally peer-reviewed.

\section{Authorship Contributions}

Surgical and Medical Practices: O.E., İ.A., Concept: O.E., Z.T., A.R., Design: O.E., Z.T., A.R., Data Collection or Processing: O.E., İ.A., Z.T., Analysis or Interpretation: O.E., Z.T., A.R., Literature Search: O.E., Z.T., A.R., Writing: O.E., Z.T., A.R.

Conflict of Interest: The authors declare there is no conflict of interest.

Financial Disclosure: The authors declare that this study did not receive any financial support.

\section{References}

1. Feig BW, Ching CD. Cancer of the Colon, Rectum, and Anus. In: Clarke CN, You YN, Feig BW, eds. The MD Anderson Surgical Oncology Handbook (6th ed.). Philadelphia; Wolters Kluwer. 2019:491-575.

2. Hamilton SR, Bosman FT, Bofetta P, Ilyas M, Morreau H, Nakamura SI, et al. Carcinoma of the colon and rectum. In: Bosman FT, Carneiro F, Hruban RH, Theise ND, eds. WHO Classification of Tumours of the Digestive System (4th ed.). Lyon, World Health Organization 2010:134-146.

3. McKittrick LS, Wheelock FC Jr. Carcinoma of the colon. Charles C. Thomas; Springfield, IL, 1954;61-63.

4. Jatzko G, Siebert F, Wolf B, Karner-Hanusch J, Kleinert R, Denk H. Combined restorative proctocolectomy and pancreaticoduodenectomy for familial adenomatous polyposis. Z Gastroenterol 1999;37:1109-1113.

5. Amersi F, Agustin M, Ko CY. Colorectal cancer: epidemiology, risk factors, and health services. Clin Colon Rectal Surg 2005;18:133-140.

6. Gschwantler M, Kriwanek S, Langner E, Göritzer B, Schrutka-Kölbl C, Brownstone $\mathrm{E}$, et al. High-grade dysplasia and invasive carcinoma in colorectal adenomas: a multivariate analysis of the impact of adenoma and patient characteristics. Eur J Gastroenterol Hepatol 2002;14:183-188.

7. Mönig SP, Selzner M, Schmitz-Rixen T. Peutz-Jeghers syndrome in a child Prolapse of a large colonic polyp through the anus. J Clin Gastroenterol 1997:25:703-704

8. Lamesch AJ. An unusual hamartomatous malformation of the rectosigmoid presenting as an irreducible rectal prolapse and necessitating rectosigmoid resection in a 14-week-old infant. Dis Colon Rectum 1983;26:452-457.

9. Utsunomiya J, Gocho H, Miyanaga T, Hamaguchi E, Kashimure A. PeutzJeghers syndrome: its natural course and management. Johns Hopkins Med J 1975;136:71-82

10. Melton GB, Kwaan MR. Rectal prolapse. Surg Clin North Am 2013;93:187198.

11. Garces M, García-Granero E, Faiz O, Alcacer J, Lledó S. Ultralow anterior resection for prolapsed giant solitary rectal polyp of Peutz-Jeghers type. Am Surg 2011;77:501-502.

12. Syngal S, Brand RE, Church JM, Giardiello FM, Hampel HL, Burt RW; American College of Gastroenterology. ACG clinical guideline: Genetic testing and management of hereditary gastrointestinal cancer syndromes. Am J Gastroenterol 2015;110:223-262.

13. Ransohoff DF, Yankaskas B, Gizlice Z, Gangarosa L. Recommendations for post-polypectomy surveillance in community practice. Dig Dis Sci 2011;56:2623-2630.

14. Hassan C, Repici A, Sharma P, Correale L, Zullo A, Bretthauer M, et al Efficacy and safety of endoscopic resection of large colorectal polyps: a systematic review and meta-analysis. Gut 2016;65:806-820. 